\title{
KOMPETENSI, KOMPENSASI DAN SANKSI HUKUM \\ PENGARUHNYA TERHADAP PERILAKU APARATUR DALAM PENGADAAN \\ BARANG/JASA DI KOTA PALEMBANG
}

(Studi Pada Pegawai/SKPD Pada Pemerintah Kota Palembang)

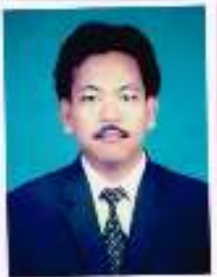

Oleh:

Dr. Yohanes Susanto, SE., M.M

(Pemerintah Sumsel)

\begin{abstract}
ABSTRAK
Kompetensi, Kompensasi dan Sanksi hukum pengaruhnya terhadap Perilaku Aparatur dalam pengadaan Barang/jasadi Kota Palembang, dibawah koordinator Lembaga penelitian Universitas In do Global Mandiri Palembang ( Program Pascasarjana Studi ekonomi Manajemen)

Penelitian ini bertujuan untuk mengkaji Pengaruh Kompetensi dan Kompensasi dan sanksi hukum pengaruhnya terhadap pengadaan Barang/jasa di Kota Palembang. Penelitian dilakukan selama 4 bulan terhadap 16 SKPD dari populasi 190 Aparatur SKPD Dinas/Badan di Kota Palembang.

Analisis data penelitian menggunakan metode statistik deskriptif dan inferensial. Model analisis menggunakan SPSS / Regresi Berganda dengan komposisi struktur Kompetensi, Kompensasi dan Sanksi Hukum sebagai variabel eksogen dan Perilaku Aparatur sebagai variabel endogen.

Hasil Penelitian menunjukan (1) pada sub-struktur pertama bahwa, Kompetensi dan Kompensasi secara bersama-sama berpengaruh positif dan signifikan terhadap perilaku aparatur, namun secara parsial hanya kompetensi yang berpengaruh positif dansignifikan (2) pada struktur utama bahwa kompetensi, kompensasi dan sanksi hukum secara bersama-sama maupun secara parsial berpengaruh positif dan signifikan terhadap perilaku aparatur di Kota Palembang.

Dari hasil analisis deskriptip dapat disimpulkan bahwa untuk meningkatkan perilaku aparatur di Kota Palembang variable sanksi hukum memiliki pengaruh lebih dominan dari pada variabel kompensasi dan variabel kompetensi indikator paling berpengaruh adalah pemalsuan dokumen lelang merupakan tindakan pidana dalam pengadaan bartang/jasa.

Disarankan kepada para aparatur di Kota Palembang, bahwa untuk meningkatkan perilaku aparatur yang baik dalam pengadaan Barang/jasa perlu perhatian di fokuskan pada upaya memperbaiki sistem kompensasi, honorarium panitia lelang dan untuk meningkatkan sanksi hukum perlu perhatian yang di fokuskan pada upaya kelengkapan lelang kepada rekanan diwajibkan meyediakan jaminan penawaran, untuk meningkatkan Kompetensi aparatur perlu adanya pembekalan tentang pemahaman pengadaan barang/jasa.
\end{abstract}

Kata Kunci : Kompetensi, Kompensasi, Sanksi hukum,dan Perilaku Aparatur

\section{Pendahuluan}

\section{Latar Belakang Masalah}

Perlu dicermati bahwa sejak diberlakukannya undang-undang nomor : 20 tahun 2001 tentang grativikasi dan undang-undang nomor : 14 tahun 2008 tentang keterbukan informasi publik, sangat berpengaruh terhadap prilaku aparatur sipil negara selaku pelaksana pengadaan barang/jasa baik secara langsung maupun tidak langsung, karakteristik yang telah terbentuk berpuluhpuluh tahun lamanya dimana sebelumnya 
para aparatur sangat semangat dan antusias ketika mendapatkan tugas dan kewenangan dari atasannya dalam kegiatan pengadaan barang/jasa baik sebagai panitia lelang, panitia penerima barang maupun pejabat pemegang komitmen/pimpro, kini paradigma tersebut telah jauh bergeser dimana sebagian besar para aparatur enggan untuk ikut dalam kegiatan pengadaan barang/jasa, sehingga tidak jarang terjadi disebagian SKPD tidak memiliki aparatur yang siap untuk masuk dalam kegiatan pengadaan barang/jasa dan harus perlu bantuan dari aparatur SKPD lainnya.

Hal tersebut diduga bahwa kesiapan aparatur dalam pengadaan barang/jasa diduga dapat dipengaruhi oleh berbagai hal antara lain, kompetensi aparatur dalam pengadaan barang/jasa dimana diataur dalam Keputusan Presiden Nomor : 80 tahun 2003 tentang Pedoman Pelaksanaan Pengadaan Barang/jasa jo Peraturan Presiden Nomor : 95 tahun 2007, bahwa dalam pengelolaan pengadaan barang/jasa Aparatur pelaksana diwajibkan memiliki sertifikasi pengadaan barang/jasa, yang ketentuannya diatur oleh lembaga yang berwenang diantaranya dari Kementerian Pekerjaan Umum (PU) Faktor lain yang di duga dapat mempengaruhi kesiapan aparatur sebagai pelaksana pengadaan barang/jasa adalah kompensasi yang diterima, kemungkinan masih sangat rendah tidak sebanding dengan beban dan tanggung jawab yang dipikul dalam jangka panjang baik mempertanggung jawabkan keuangan negara maupun mempertanggung jawabkan fisik kekayaan negara, dan pengaruh lain yang di duga paling dominan dapat mempengaruhi kesiapan aparatur sebagai pelaksana pengadaan barang/jasa adalah ancaman sanksi hukum yang akan diterima oleh penyelenggara negara/pelaksana pengadaan barang/jasa apabila ternyata dikemudian hari ada pelanggaran hukum yang dilakukjan baik dengan sengaja maupun tidak disengaja akibat kelalaiannya. Dari informasi yang penulis peroleh dari penyidik KPK Bapak Dr. H. Abudulah Hehahua. MM (2015) mengatakan bawah kasus korupsi di Indonesia ternyata $48 \%$ adalah kasus pengadaan barang/jasa belum lagi kasus lain yang ada hubungannya dalam pengadaan barang/jasa seperti pada saat pengajuan anggaran baik melalui APBD maupun APBN yang mekanismenya melibatkan banyak pihak termasuk panitia anggaran di duga memerlukan negosiasi anggaran.

Mencermati ruang gerak yang di emban oleh aparatur sebagai pelaksana pengadaan barang/jasa dirasakan cukup berat bila tidak didukung oleh kompetensi yang profisional dan mempunyai pengalaman yang cukup serta memiliki kemampuan koordinasi dengan instansi/lembaga yang terkait, maka dimungkinkan akan dapat menjadi boomerang si aparatur itu sendiri, oleh karenanya penulis berupaya melakukan penelitian tentang kesiapan aparatur Pemerintah Kota Palembang dalam melaksanakan pengadaan barang/jasa serta bebarapa variabel di duga dapat mempengaruhinya, penelitian ini akan membahas permasalahan prilaku aparatur Pemerintah dari tiga aspek penting yaitu :

1. Aspek Kompetensi aparatur dalam pengadaan barang/jasa yang didukung dengan sertifikasi.

2. Aspek Kompensasi yang diterima oleh aparatur yang terlibat dalam pengadaan barang/jasa. 
3. Aspek sanksi hukum yang diterapkan kepada aparatur yang melakukan pelanggaran dalam pengadaan barang/jasa.

Sehingga dengan demikian diharapkan hasil dari penelitian ini dapat diketahui aspek mana dari ketiga aspek tersebut yang perlu diperbaiki untuk meningkatkan dapat memberikan motivasi kerja kepada aparatur sebagai pelaksana pengadaan barang/jasa, dan pada akhirnya akan meningkatkan profesionalitas aparatur yang bersih, beribawa serta bertanggung jawab atas tugas dan kewjiban yang diberikan kepadanya.

\section{Identifikasi Masalah}

1. Kompetensi yang dimiliki sebagian aparatur yang terlibat dalam kegiatan pengadaan barang/jasa di Kota Palembang, cenderung kurang kompeten, diidentifikasi berpengaruh pada perilaku aparatur dalam pengadaan barang/jasa

2. Kepemimpinan yang ada pada beberapa SKPD tidak memberikan kebebasan berkreasi dan berafiliasi kepada bawahan dalam pengadaan barang/jasa, sehingga diidentifikasi mempengaruhi perilaku aparatur dalam pengadaan barang/jasa di Kota Palembang.

3. Kompensasi yang diterima para aparatur yang terlibat dalam kepanitiaan, Pejabat Pemegang Komitmen dan Panitia penerima barang/jasa di Kota Palembang diidentifikasi relatif rendah akan mempengaruhi kemauan atau perilaku aparatur dalam pengadaan barang/jasa.

4. Motivasi kerja para aparatur di beberapa SKPD, utamanya mereka yang mempunyai kompetensi dalam pengadaan barang/jasa relatif masih rendah diidentifikasi akan berpengaruh terhadap perilaku aparatur

5. Komitmen yang telah disepakati bersama pada organisasi SKPD seringkali dilanggar dan di duga akan mengakibatkan ketidak percayaan aparatur dalam mengembangkan diri kegiatan pengadaan barang/jasa

6. Kurangnya perhatian dari pimpinan atas hasil kerja bawahan dalam pengadaan barang dan jasa, sehingga menimbulkan rasa ketidak puasan para aparatur dan akhirnya diduga akan mempengaruhi perilaku aparatur.

7. Pembagian tugas pada bawahan terhadap kepanitiaan pengadaan barang/jasa,sehingga menimbulkan rasa ketidakadilan dan pada akhirnya didentifikasi akan mempengaruhi perilaku aparatur dalam pengadaan barang/jasa.

8. Lingkungan kerja yang kurang kondusif antara sesama aparatur dan pimpinan sehingga menimbulkan ketidak puasan dan akhirnya diidentifikasi mempengaruhi perilaku aparatur dalam pengadaan barang/jasa.

9. Sarana penunjang yang belum terpenuhi,diduga akan menimbulkan ketidak puasan para aparatur dan pada akhirnya akan mempengaruhi perilaku aparatur dalam pengadaan barang/jasa.

10. Ancaman sanksi hukum yang dihadapi oleh para aparatur yang terlibat dalam pengadaan barang/jasa dirasakan cukup merepotkan diduga akan 
mempengaruhi perilaku aparatur dalam pengadaan barang/jasa.

11. Fasilitasi pembelaan hukum yang diterima tidak memuaskan di kemudian hari ketika terjadi pelanggran aparatur dalam pengadaan barang/jasa

12. Timbulnya tekanan-tekanan dari berbagai pihak, antara lain atasan langsung, teman sejawat, pihak legeslatif, lembaga swadaya masyarakat yang mengambil kesempatan dengan menggunakan perangkat aturan yang ada di duga akan mempengaruhi perilaku apartur dalam pengadaan barang/jasa.

\section{Pembatasan Masalah}

Banyak faktor yang diidentifikasi di duga dapat mempengaruhi perilaku aparatur dalam pengadaan barang/jasa, sehingga dalam penelitian ini dibatasi hanya mengenai pengaruh Kompetensi, kompensasi dan sanksi hukum di beberapa SKPD Kota Palembang.

\section{Perumusan Masalah}

Berdasarkan identifikasi masalah di atas, maka dapat disusun sejumlah rumusan masalah sebagai berikut:

1. Apakah terdapat pengaruh Kompetensi terhadap Perilaku Aparatur dalam pengadaan barang/jasa di Kota Palembang?

2. Apakah terdapat pengaruh Kompensasi terhadap Perilaku Aparatur dalam pengadaan barang/jasa di Kota Palembang?

3. Apakah terdapat pengaruh Kompetensi dan Kompensasi secara bersama-sama terhadap Perilaku Aparatur dalam pengadaan barang/jasa diKota Palembang?

4. Apakah terdapat pengaruh Sanksi Hukum terhadap perilaku aparatur dalam pengadaan barang/jasa di Kota Palembang?

5. Apakah terdapat pengaruh Kompetensi, Kompensasi dan Sanksi hukum secara bersamasama terhadap perilaku aparatur pengadaan barang/jasa di Kota Palembang?

\section{Tujuan Penelitian}

Berdasarkan rumusan masalah di atas, maka dapat disusun sejumlah tujuan penelitian yaitu untuk mengetahui :

1. Pengaruh Kompetensi terhadap Perilaku Aparatur dalam pengadaan barang/jasa di Kota Palembang.

2. Pengaruh kompensasi terhadap Perilaku Aparatur dalam pengadaan barang/jasa di Kota Palembang.

3. Pengaruh Kompetensi, Kompensasi secara bersama-samaterhadap Sanksi Hukum dalam pengadaan barang/jasa di Kota Palembang.

4. Pengaruh Sanksi hukum terhadap perilaku aparatur dalam pengadaan barang/jasa di Kota Palembang.

5. Pengaruh Kompetensi,Kompensasi dan Sanksi hukum secara bersamasama terhadap perilaku aparatur pengadaan barang/jasa di Kota Palembang.

\section{Kegunaan Penelitian}

Penelitian ini akan dapat memberikan sumbangan baik secara teoritis maupun praktis sebagai berikut : 
1. Secara teoritis, Penelitian ini akan dapat memberikan sumbangan dalam aspek teoritis (keilmuan) yaitu bagi perkembangan ilmu Ekonomi Manajemen, khususnya pada bidang Manajemen Sumberdaya Manusia, melalui pendekatan aspek Kompetensi, Kompensasi, sanksi hukum dan perialaku aparatur dalam pengadaan barang/jasa.

2. Secara empirik, Penelitian ini dapat memberikan sumbangan

\section{Tinjauan Pustaka}

\section{Kompetensi}

Kompetensi adalah seperangkat tingkah laku, keterampilan dan pengetahuan tertentu yang menjadi syarat utama dan elemen kunci bagi lahirnya kepemimpinan yang efektif dan efisien (Siagian,1997).

Secara umum kompetensi dipahami sebagai sebuah kombinasi antara keterampilan (skill), atribut personal dan pengetahuan (knowledge) yang tercermin melalui perilaku kinerja (job behavior) yang dapat diamati, diukur dan dievaluasi. Kompetensi adalah kemampuan dan karakteristik yang dimiliki oleh seseorang berupa pengetahuan, keterampilan, dan sikap perilaku yang diperlukan dalam pelaksanaan tugas jabatannya, sehingga dapat melaksanakan tugasnya secara profesional, efektif dan efisien serta sesuai dengan standar kinerja yang diisyaratkan. (Depkes RI, 2006)

\section{Kompensasi}

Kompensasi merupakan salah satu faktor baik secara langsung maupun tidak langsung mempengaruhi tinggi rendahnya motivasi dan kinerja Perilaku Aparatur,

\begin{abstract}
dalam aspek praktis (guna laksana) yaitu untuk memberikan sumbangan pemikiran bagi perkembangan pembinaan aparatur Pemerintah dalam pengadaan barang/jasa, di Kota Palembang, terutama yang menyangkut Kompetensi, Kompensasi dan Sanksi hukum, sehingga menghasilkan aparatur yang bersih, beribawa serta bertanggung jawab atas kinerjanya.
\end{abstract}

oleh. karena itu semestinya pemberian kompensasi perlu mendapat perhatian khusus dari pihak penyelenggara pengadaan agar motivasi dapat dipertahankan dan kinerjanya diharapkan akan terus meningkat. Berkaitan dengan hal tersebut perlu diadakan penelitian mengenai variabel yang mempengaruhi Kompensasi merupakan sebagai akibat yang ditumbulkan atas konsekuensi dari hasil penilaian tersebut. (Sulistiyani, Rosidah, 2009 : 16).

Tujuan organisasi-organisasi yang melaksanakan merit pay/ kompensasi adalah untuk meningkatkan kinerja dari para karyawan. Hal ini dikarenakan system penghargaan ini memotivasi karyawan untuk meningkatkan kinerjanya. (Usmara, 2003 : 217). Kompensasi adalah seluruh nilai extrinsic reword yang diterima oleh karyawan dalam bentuk upah atau gaji, insentif atau bonus dan beberapa tunjangan (benefit). (Fajar, $2010: 154$

\section{Sanksi Hukum}

Dalam proses pengadaan barang/jasa, berdasarkan pelimpahan kewenangan diwakili oleh pejabat-pejabat pengadaan, yaitu: (1) PA/KPA, (2) Pejabat Pembuat Komitmen (PPK), (3) Kelompok 
Kerja Unit Layanan Pengadaan/Pejabat Pengadaan (PPK/PP), dan Panitia/Pejabat Penerima Hasil Pekerjaan (PPPHP). Sedangkan Penyedia Barang/Jasa bisa orang perorangan atau badan hukum (privat). Para Pejabat Pengadaan dalam melakukan hubungan hukum di bidang perjanjian bertindak secara individual/pribadi. Artinya, apabila terdapat kerugian negara maka mengganti kerugian negara tersebut secarapribadi, sebagaimana ditentukan dalam UndangUndang No. 1 Tahun 2004 tentang Perbendaharan, Pasal 18 ayat 3 yang berbunyi "Pejabat yang menandatangani dan/atau mengesahkan dokumen yang berkaitan dengan surat bukti yang menjadi dasar pengeluaran atas beban APBN/APBD bertanggung jawab atas kebenaran material dan akibat yang timbul dari penggunaan surat bukti dimaksud". Berdasarkan Perpres No. 70 Tahun 2012 tentang Pengadaan Barang/Jasa Pemerintah, Pasal 55 ayat (1) bahwa tanda bukti perjanjian terdiri atas (1) bukti pembelian, (2) kuitansi, (3) Surat Perintah Kerja (SPK), dan (5) surat perjanjian. Dalam Kitab Undang-Undang Hukum Perdata (KUH Perdata), buku III tentang Perikatan, disebutkan bahwa perikatan dapat lahir karena undang-undang atauperjanjian. Perikatan yang lahir karena perjanjian Pasal 1338 KUH Perdata menyatakan bahwa "Semua perjanjian yang dibuat harus memenuhi syarat-syarat Maksudnya, semua perjanjian mengikat mereka yang tersangkut bagi yang membuatnya, mempunyai hak yang oleh perjanjian itu diberikan kepadanya dan berkewajiban melakukan hal-hal yang ditentukan dalam perjanjian.Perjanjian dalam pengadaan barang/jasa adalah suatu persetujuan dengan mana pihak yang satu menyelenggarakan suatu pekerjaan bagi pihak lain dengan menerima suatu harga tertentu. Perjanjian merupakan dasar pelaksanaan kegiatan. Perjanjian menurut R. Subekti adalah "suatu peristiwa dimana seseorang berjanji kepada orang lain atau dimana dua orang itu saling berjanji untuk melakukan sesuatu hal". Setiap orang atau badan hukum dapat mengadakan perjanjian, asalkan memenuhi syaratsyarat yang ditetapkan dalam KUH Perdata. Syarat-syarat yang ditetapkan dalam KUH Perdata tercantum dalam pasal 1320 sebagai berikut :

1) Kata sepakat antara mereka yang mengikatkan dirinya;

2) Kecakapan untuk membuat suatu perjanjian;

3) Suatu hal tertentu; dan

4) Suatu sebab yang halal.

Jadi untuk sahnya suatu perjanjian haruslah memenuhi syarat-syarat seperti yangdiatur dalam pasal $1320 \mathrm{KUH}$ Perdata dimaksud. Selanjutnya berdasarkan Pasal1338 KUH Perdata, bahwa setiap orang bebas mengadakan perjanjian asalmemenuhi syarat-syarat yang ditentukan. Oleh karena itu, perjanjian mempunyai "sistem terbuka".Dengan demikian, perjanjian dapat dilakukan oleh setiap subjek hukum antara lain perjanjian jual beli, perjanjian sewa-menyewa, pinjam meminjam, tukar menukar, perjanjian kerja pemborongan dan sebagainya. Berkaitan dengan pengadaan barang/jasa pemerintah, bentuk perjanjiannya berupa kontrak pengadaan barang/jasa yaitu dalam bentuk perjanjian tertulis antara PPK dengan Penyedia Barang/Jasa atau pelaksana swakelola. Dalam hukum perjanjian hak dan kewajiban para pihak dalam perjanjian bersifat timbal balik, dimana hak pada satu 
pihak merupakan kewajiban pihak lain, begitu pula sebaliknya. Hak dan kewajiban para pihak merupakan hak-hak yang dimiliki serta kewajiban yang harus dilaksanakan baik oleh pengguna barang/jasa maupun penyedia barang/jasa dalam melaksanakan kontrak. Dalam perjanjian pemborongan, hak dan kewajiban para pihak adalah pengguna barang/jasa.Pengguna barang/jasa menerima hasil pekerjaan melalui PPK, yang sebelumnya dilakukan oleh Panitia/Pejabat Penerima Hasil Pekerjaan (PPPHP) sesuai dengan isi perjanjian. Sedangkan kewajiban PA/KPA adalah membayar harga dari pekerjaan yang telah dilaksanakan. Selanjutnya Hak pihak pemborong/penyedia adalah menerima pembayaran sesuai dengan harga kontrak dari pihak yang memborongkan pekerjaan (pengguna). Sedangkan kewajiban penyedia adalah menyelesaikan pekerjaan sesuai dengan isi kontrak. Hak dan kewajiban para pihak di atas biasa disebut sebagai hak dan kewajiban yang utama/pokok dari para pihak, sementara hak dan kewajiban tambahan diatur secara khusus dalam kontrak/perjanjian. Tindak pidana dalam pengadaan barang/jasa pemerintah titik rawan penyimpangan terjadi pada tahap perencanaan pengadaan, seperti adanya indikasi penggelembungan anggaran atau mark-up, pelaksanaan pengadaan yang diarahkan, rekayasana penyatuan dan/atau memecah-mecah dengan maksud Kolusi, Korupsi maupun Nepotisme yang merugikan negara, Selain tersebut di atas, titik rawan tindak pidana lainnya juga bisa terjadi pada tahap kualifikasi perusahaan, tahap evaluasi pengadaan, tahap penandatangan kontrak, dan tahap penyerahan barang yang tidak memenuhi syarat dan bermutu rendah yang dapat menimbulkan kerugian negara. Di samping itu, Penyedia Barang/Jasa titik rawan tindak pidana dapat terjadi pada tindak pemalsuan dokumen, ingkar janji untuk melaksanakan pekerjaan (wanprestasi) sehingga terdapat unsur perbuatan melanggar hukum yang mengakibatkan kerugian bagi negara. Namun hal yang perlu diperhatikan dalam hukum pidana adalah asas yang mengatakan "tindak pidana tanpa kesalahan". Untuk menjatuhkan pidana kepada orang yang melakukan tindak pidana harus dilakukan bilama mana ada unsur kesalahan pada diri orang tersebut. Bahkan di dalam asas lain dikatakan "Presumption of innocence", biasa juga disebut asas praduga tidak bersalah, yaitu bahwa seseorang dianggap tidak bersalah sebelum ada putusan hakim yang menyatakan ia bersalah, dan putusan hakim tersebut telah mempunyai kekuatan hukum tetap. Dari pengertian sanksi Hukum diatas, maka dapat disimpulkan bahwa sanksi Hukum adalah perbuatan seseorang selaku penyelenggara Negara dalam pengadaan barang/jasa bertindak atas nama individu melakukan kelalaian, menerima suap, pemalsuan dokumen dan penyalagunaan wewenang sehingga mengakibatkan kerugian Negara, kepadanya dapat dikenakan sanksi Hukum atau tidakan Hukum.

\section{Perilaku Aparatur}

Katharine \& Briggs Myers (1980) mengemukakan bahwa untuk mengukur keperibadian seseorang ada empat analisis meliputi :

1. Orientasi terhadap Energi

a. Extraversion (Stimulasi datangnya dari luar) tipe peribadi seperti ini suka dengan dunia luar senang bergaul, menyenangi interaksi 
sosial dengan orang lain, baik untuk berurusan dengan orang luar.

b. Intraversion (Stimulus dari dalam) senang dengan diri sendiri, senang menyendiri, merenung, membaca, menulis dan tidak begitu nsuka bergaul dengan orang banyak.

2. Proses pembentukan persepsi.

a. Sensing (Kelima Indra) mereka dalam memproses data selalu dengan fakta yang kongkrit, praktis dan realistis melihat data dengan apa adanya dan melihat cara yang telah terbukti.

b. Intuition (Suara hati) mereka berfikir abstrak, konseptual melihat kemungkinan apa yang terjadi, berpedoman pada imajinasi terfokus pada masa depan yang kan terjadi, penuh inovatif dan inspirasi ide dan visi masa depan.

3. Proses pengambilan keputusan

a. Thinking (logika) mereka melibatkan perasaan, empati saerta nilai-nilai yang diyakini ketika akan mengambil keputusan. b. Feeling (Perasaan) mereka melibatkan perasaan, empati serta nilai-nilai yang diyakini ketika mengambil keputusan

4. Perilaku individu terhadap dunia luar.

a. Jadging (Terjadwal) tipe orang yang bertumpu pada rencana yang sistematis, berfikir dan bertrindak secara teratur tidak suka akan halhal yang mendesak diluar rencana.

b. Perceiving (Lingkungan sendiri) mereka yang suka mendesak, spontan untuk melihat peluang yang muncul dan bertindak secara acak, baik bagi orang yang mampu menghadapi perubahan dan situasi secara mendadak.

\section{Kerangka Pemikiran}

Berdasarkan uraian sebelumnya, maka dapat dianalisis bahwa apakah Kompetensi, Kompensasi dan Sanksi Hukum berpengaruh terhadap Perilaku Aparatur dalam pengadaan barang/jasa di Kota Palembang analisis ini dituangkan dalam model kerangka konseptual berikut ini :

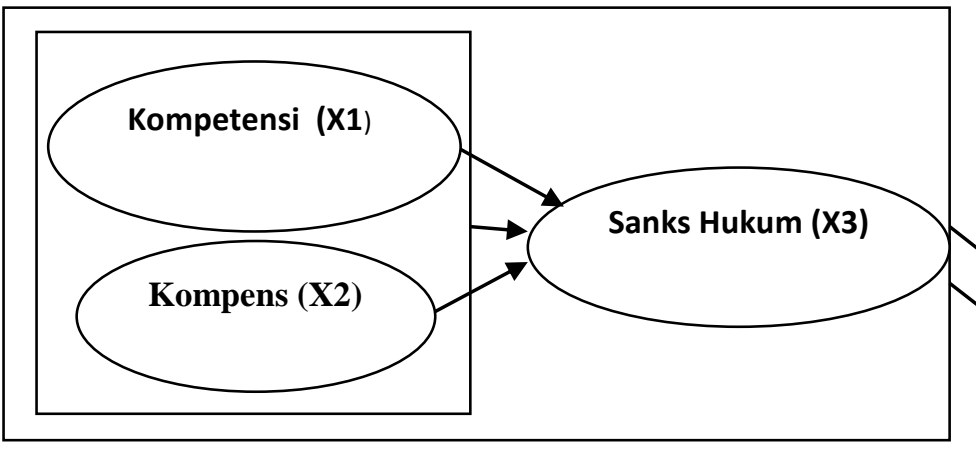

Kerangka Berpikir

Perilaku

Aparatur (Y)

Hipotesis Penelitian :

1. Terdapat pengaruh signifikan Kompetensi terhadap Perilaku Aparatur dalam pengadaan barang/jasa di Kota Palembang
2. Terdapat pengaruh signifikan Kompensasi terhadap perilaku aparatur dalam pengadaan barang/jasa di Kota Palembang 
3. Terdapat pengaruh signifikan Kompetensi dan Kompensasi secara bersama-sama terhadap perilaku aparatur dalam pengadaan barang/jasa di Kota Palembang

4. Terdapat pengaruh signifikan Sanksi hokum terhadap Perilaku aparatur dalam pegadaan barang/jasa di Kota Palembang

5. Terdapat pengaruh signifikan antara Kompetensi dan sanksi hukum secara bersama-sama terhadap perilaku aparatur dalam pengadaan barang/jasa di Kota Palembang.

\section{Metode Penelitian}

\section{Populasi dan Sampel}

Populasi yang menjadi objek adalah seluruh pegawai di lingkungan Dinasdinas ditunjuk sebagai pengelola pengadaan barang/jasa di Kota Palembang, berjumlah 190 orang pegawai, pada 16 Dinas/Badan

Teknik penetuan sampel menggunakan proporsional random sampling dengan rincian sebagai berikut :

\section{Uji Instrumen}

a. Uji Validitas

Uji validitas dilakukan dengan membandingkan nilai $\mathrm{r}$ hitung (untuk setiap butir pertanyaan dapat dilihat pada kolom corrected item-), dengan $r$ tabel dengan mencari degree of freedom (df)=N-kJikar hitung $>r$ tabel, dan bernilai positif, maka pertanyaan (indikator) tersebut dikatakan valid (Ghozali, 2006).

b. Uji Reliabilitas Untuk mengukur reliabilitas dilakukan dengan uji statistic Cronbach Alpha $(\alpha)$. Suatu variabel dikatakan reliabel jika memberikan nilai $\alpha>0,60$ (Nunnally dikutip oleh Ghozali
2006). Analisis Regresi Linier Berganda Analisis regresi linier berganda yaitu analisi yang bertujuan untuk mengetahui ada tidaknya hubungan ketergantungan, dan arah hubungan ketergantungan antara dua atau lebih variabel bebas dengan variabel terikatapakah positif atau negatif (Priyatno, 2008). Adapun persamaan regresi linier bergandanya adalah sebagai berikut :

$\mathrm{Y}=\mathrm{a}+\mathrm{b} 1 \mathrm{X} 1+\mathrm{b} 2 \mathrm{X} 2+\mathrm{b} 3 \mathrm{X} 3+\mathrm{e}$

Dimana:

$\mathrm{Y} \quad=$ Variabel dependen (kinerja pegawai)

$\mathrm{X} 1=$ Variabel independen (gaya kepemimpinan)

$\mathrm{X} 2$ = Variabel independen (motivasi kerja)

$\mathrm{A} \quad=$ Konstanta

b1, b2 = Koefisien regresi

e = Variabel lain yang tidak diteliti atau dimasukkan dalam model

\section{Uji Hipotesis}

Pengujian hipotesis dilakukan untuk memperoleh kebenaran atas apa yang telah di hipotesiskan di bab tinjauan terdahulu.

a. Uji Hipotesis Secara Simultan (Uji

F) Uji statistik $F$ pada dasarnya menunjukkan apakah semua variable ndependen atau bebas yang dimasukkan berpengaruh secara bersama-sama terhadap variabel dependen atau terikat (Ghozali, 2006)

b. Cara pengujiannya adalah berdasarkan probabilitas. Bila probabilitas lebih besar daripada 0,05 $(\alpha)$, maka variabel bebas secara serentak tidak berpengaruh variabel terikat. Sedangkan bila probabilitas lebih kecil daripada 
0,05 ( $\alpha)$, maka variabel bebas secara serentak berpengaruh terhadap variabel terikat.

c. Uji Koefisien Determinasi (R2)

Koefisien determinasi

dimaksudkan untuk mengukur kemampuan seberapa besar persentase variasi variabel bebas (independen) pada model regresi linear berganda dalam menjelaskan variasi variabel terikat (dependen) (Priyatno,2008). Dengan kata lain pengujian model menggunakan (R2), dapat menunjukkan bahwa variabelvariabel independen yang digunakan dalam model regresi linear berganda adalah variabel-variabel independen yang mampu mewakili keseluruhan dari variabel-variabel independen lainnya dalam mempengaruhi variable dependen, kemudian besarnya pengaruh ditunjukkan dalam bentuk persentase.

d. Uji t

Uji statistik $t$ pada dasarnya menunjukkan seberapa jauh pengaruh satu variabel penjelas/ independen secara individual dalam menerangkan variasi variabel dependen Ghozali, 2006).

Cara melakukan uji $\mathrm{t}$ adalah sebagai berikut:

1. Membandingkan hasil besarnya peluang melakukan kesalahan (tingkat signifikansi) yang muncul, dengan tingkat peluang munculnya kejadian (probabilitas) yang ditentukan sebesar $5 \%$ atau 0,05 pada output:

a. Apabila signifikansi > 0.05 maka keputusannya adalah menerima Hodan menolak Ha

b. Apabila signifikansi $<0.05$ maka keputusannya adalah menolak Ho danmenerima $\mathrm{Ha}$

2. Membandingkan nilai statistik t hitung dengan nilai statistik t tabel:

a. Apabila nilai statistik t hitung < nilai statistik tabel, maka Ho diterima

b. Apabila nilai statistik t hitung > nilai statistik tabel, maka Ho ditolak.

\section{Hasil Dan Pembahasan}

Uji Validasi

Variabel Kompetensi

\begin{tabular}{|l|c|c|c|c|}
\hline & $\begin{array}{c}\text { Scale Mean if } \\
\text { Item Deleted }\end{array}$ & $\begin{array}{c}\text { Scale Variance } \\
\text { if Item Deleted }\end{array}$ & $\begin{array}{c}\text { Corrected Item- } \\
\text { Total Correlation }\end{array}$ & $\begin{array}{c}\text { Cronbach's Alpha if } \\
\text { Item Deleted }\end{array}$ \\
\hline KP01 & $\mathbf{5 4 . 2 0}$ & $\mathbf{2 4 . 9 8 0}$ & .468 & .809 \\
KP02 & $\mathbf{5 4 . 2 2}$ & 25.522 & .539 & .806 \\
KP03 & $\mathbf{5 4 . 2 4}$ & 25.778 & .497 & .809 \\
KP04 & $\mathbf{5 4 . 5 0}$ & 26.582 & .343 & .817 \\
KP05 & $\mathbf{5 4 . 3 6}$ & 25.582 & .507 & .808 \\
KP06 & $\mathbf{5 4 . 6 6}$ & 27.045 & .287 & .820 \\
KP07 & $\mathbf{5 4 . 2 6}$ & 26.809 & .288 & .820 \\
KP08 & $\mathbf{5 4 . 1 6}$ & $\mathbf{2 4 . 5 0 4}$ & .592 & .801 \\
KP09 & $\mathbf{5 4 . 5 2}$ & 22.785 & .482 & .813 \\
KP10 & $\mathbf{5 4 . 3 6}$ & $\mathbf{2 4 . 0 3 1}$ & .629 & .797 \\
KP11 & $\mathbf{5 4 . 6 4}$ & $\mathbf{2 4 . 2 3 5}$ & .427 & .814
\end{tabular}




\begin{tabular}{|l|l|l|l|l|} 
KP12 & $\mathbf{5 4 . 4 0}$ & $\mathbf{2 4 . 0 8 2}$ & .641 & .797 \\
KP13 & $\mathbf{5 4 . 5 0}$ & $\mathbf{2 6 . 0 1 0}$ & .413 & .813 \\
KP14 & $\mathbf{5 4 . 5 2}$ & $\mathbf{2 5 . 7 2 4}$ & .317 & .821 \\
\hline
\end{tabular}

Variabel Kompensasi

\begin{tabular}{|l|c|c|c|c|}
\hline & $\begin{array}{c}\text { Scale Mean if } \\
\text { Item Deleted }\end{array}$ & $\begin{array}{c}\text { Scale Variance } \\
\text { if Item Deleted }\end{array}$ & $\begin{array}{c}\text { Corrected Item- } \\
\text { Total Correlation }\end{array}$ & $\begin{array}{c}\text { Cronbach's Alpha if } \\
\text { Item Deleted }\end{array}$ \\
\hline KO01 & 23.98 & 6.673 & .480 & .748 \\
KO02 & 23.28 & 7.104 & .542 & .732 \\
KO03 & 23.72 & 6.696 & .491 & .744 \\
KO04 & 23.44 & 8.374 & .353 & .768 \\
KO05 & 23.48 & 6.744 & .584 & .722 \\
KO06 & 23.58 & 5.840 & .725 & .683 \\
KO07 & 23.40 & 8.531 & .289 & .775 \\
\hline
\end{tabular}

Variabel Sanksi Hukum

\begin{tabular}{|c|c|c|c|c|}
\hline & $\begin{array}{c}\text { Scale Mean if } \\
\text { Item Deleted }\end{array}$ & $\begin{array}{c}\text { Scale Variance } \\
\text { if Item Deleted }\end{array}$ & $\begin{array}{c}\text { Corrected Item- } \\
\text { Total Correlation }\end{array}$ & $\begin{array}{c}\text { Cronbach's Alpha if } \\
\text { Item Deleted }\end{array}$ \\
\hline SH1 & 27.08 & 14.483 & .562 & .754 \\
SH2 & 27.16 & 15.117 & .365 & .775 \\
SH3 & 27.26 & 13.992 & .573 & .748 \\
SH4 & 27.02 & 15.122 & .422 & .769 \\
SH5 & 26.92 & 14.769 & .457 & .764 \\
SH6 & 27.62 & 13.138 & .542 & .747 \\
SH7 & 28.50 & 10.949 & .599 & .741 \\
SH8 & 28.24 & 10.717 & .581 & .750 \\
\hline
\end{tabular}

Variabel Perilaku Aparatur

\begin{tabular}{|l|c|c|c|c|}
\hline & $\begin{array}{c}\text { Scale Mean if } \\
\text { Item Deleted }\end{array}$ & $\begin{array}{c}\text { if Item Deleted } \\
\text { if }\end{array}$ & $\begin{array}{c}\text { Corrected Item- } \\
\text { Total Correlation }\end{array}$ & $\begin{array}{c}\text { Cronbach's Alpha if } \\
\text { Item Deleted }\end{array}$ \\
\hline PA1 & 27.40 & 10.245 & .607 & .675 \\
PA2 & 27.36 & 10.276 & .608 & .675 \\
PA3 & 27.88 & 9.781 & .654 & .662 \\
PA4 & 27.56 & 10.496 & .516 & .692 \\
PA5 & 27.14 & 12.327 & .372 & .724 \\
PA6 & 28.46 & 10.621 & .254 & .772 \\
PA7 & 27.40 & 12.286 & .319 & .729 \\
PA8 & 27.44 & 11.966 & .271 & .738 \\
\hline
\end{tabular}

Dari ke empat table di atas dapat disimpulkan bahwa seluruh butir pertanyaan pada kuesioner variabel Kompetensi, Kompensasi, Sanksi Hukum dan Variabel Perilaku Aparatur valid, karena seluruhnya memiliki nilai Corrected Item-Total Correlation $\geq 0,25$. 
Uji Reliabilitas

\begin{tabular}{|l|l|l|l|}
\hline Variabel & $\begin{array}{l}\text { Crobach's } \\
\text { Alpha }\end{array}$ & $\begin{array}{l}\text { N of } \\
\text { Items }\end{array}$ & Status \\
\hline Kompetensi &, 882 & 50 & Reliabel \\
\hline Kompensasi &, 770 & 50 & Reliabel \\
\hline Sanksi Hukum &, 784 & 50 & Reliabel \\
\hline Perilaku Aparatur &, 737 & 50 & Reliabel \\
\hline
\end{tabular}

Analisis Deskriptif

Distribusi Jawaban Responden pada Variabel Kompetensi

\begin{tabular}{|c|c|c|c|c|c|c|c|c|c|}
\hline \multirow[b]{2}{*}{ No } & \multirow[b]{2}{*}{ Indikator } & \multicolumn{5}{|c|}{ Frekuensi Jawaban } & \multirow{2}{*}{$\begin{array}{c}\text { Skor } \\
\text { Empirik }\end{array}$} & \multirow[b]{2}{*}{$\begin{array}{l}\text { Nilai } \\
\text { Maks }\end{array}$} & \multirow{2}{*}{$\begin{array}{c}\text { Pencapaian } \\
(\%)\end{array}$} \\
\hline & & $\begin{array}{c}\text { STS } \\
(1)\end{array}$ & $\begin{array}{l}\text { TS } \\
\text { (2) }\end{array}$ & $\begin{array}{c}\mathbf{R} \\
(3)\end{array}$ & $\begin{array}{c}S \\
(4)\end{array}$ & $\begin{array}{l}\text { SS } \\
(5)\end{array}$ & & & \\
\hline 1 & KP01 & 1 & 0 & 2 & 97 & 90 & 845 & 950 & 88.95 \\
\hline 2 & KP02 & 0 & 0 & 2 & 107 & 81 & 839 & 950 & 88.32 \\
\hline 3 & KP03 & 0 & 0 & 6 & 111 & 73 & 827 & 950 & 87.05 \\
\hline 4 & KP04 & 0 & 1 & 15 & 124 & 50 & 793 & 950 & 83.47 \\
\hline 5 & KP05 & 1 & 2 & 10 & 112 & 65 & 808 & 950 & 85.05 \\
\hline 6 & KP06 & 0 & 3 & 19 & 136 & 32 & 767 & 950 & 80.74 \\
\hline 7 & KP07 & 0 & 0 & 9 & 91 & 90 & 841 & 950 & 88.53 \\
\hline 8 & KP08 & 0 & 1 & 14 & 104 & 71 & 815 & 950 & 85.79 \\
\hline 9 & KP09 & 3 & 11 & 14 & 112 & 50 & 765 & 950 & 80.53 \\
\hline 10 & KP10 & 0 & 1 & 10 & 122 & 57 & 805 & 950 & 84.74 \\
\hline 11 & KP11 & 5 & 29 & 14 & 101 & 41 & 714 & 950 & 75.16 \\
\hline 12 & KP12 & 0 & 1 & 24 & 112 & 53 & 787 & 950 & 82.84 \\
\hline 13 & KP13 & 0 & 5 & 25 & 118 & 42 & 767 & 950 & 80.74 \\
\hline 14 & KP14 & 2 & 7 & 11 & 118 & 52 & 781 & 950 & 82.21 \\
\hline & Imlah & 12 & 61 & 175 & 1565 & 847 & 11154 & 13300 & 83.86 \\
\hline
\end{tabular}

Sumber: Hasil Kuesioner Penelitian, 2015 (diolah)

Ket: STS= Sangat Tidak Setuju, TS=Tidak Setuju, R=Ragu-ragu, S=Setuju, SS=Sangat Setuju

Distribusi Jawaban Responden pada Variabel Kompensasi

\begin{tabular}{|c|c|c|c|c|c|c|c|c|c|}
\hline \multirow[b]{2}{*}{ No } & \multirow[b]{2}{*}{ Indikator } & \multicolumn{5}{|c|}{ Frekuensi Jawaban } & \multirow{2}{*}{$\begin{array}{c}\text { Skor } \\
\text { Empirik }\end{array}$} & \multirow[b]{2}{*}{$\begin{array}{l}\text { Nilai } \\
\text { Maks }\end{array}$} & \multirow{2}{*}{$\begin{array}{c}\text { Pencapaian } \\
(\%)\end{array}$} \\
\hline & & $\begin{array}{l}\text { STS } \\
(1)\end{array}$ & $\begin{array}{l}\text { TS } \\
(2)\end{array}$ & $\begin{array}{l}\mathbf{R} \\
\text { (3) }\end{array}$ & $\begin{array}{c}S \\
(4)\end{array}$ & $\begin{array}{l}\text { SS } \\
(5)\end{array}$ & & & \\
\hline 1 & KO1 & 3 & 19 & 57 & 76 & 35 & 691 & 950 & 72.74 \\
\hline 2 & KO2 & 0 & 3 & 8 & 106 & 73 & 819 & 950 & 86.21 \\
\hline 3 & KO3 & 0 & 6 & 37 & 109 & 38 & 749 & 950 & 78.84 \\
\hline 4 & KO4 & 6 & 43 & 35 & 62 & 44 & 665 & 950 & 70.00 \\
\hline 5 & KO5 & 0 & 0 & 27 & 82 & 81 & 814 & 950 & 85.68 \\
\hline 6 & KO6 & 0 & 2 & 41 & 76 & 71 & 786 & 950 & 82.74 \\
\hline
\end{tabular}




\begin{tabular}{|c|c|c|c|c|c|c|c|c|c|}
\hline 7 & KO7 & 0 & 0 & 9 & 92 & 89 & 840 & 950 & 88.42 \\
\hline \multicolumn{2}{|c|}{ Jumlah } & $\mathbf{9}$ & $\mathbf{7 3}$ & $\mathbf{2 1 4}$ & $\mathbf{6 0 3}$ & $\mathbf{4 3 1}$ & $\mathbf{5 3 6 4}$ & $\mathbf{6 6 5 0}$ & $\mathbf{8 0 . 6 6}$ \\
\hline
\end{tabular}

Sumber: Hasil Kuesioner Penelitian, 2015 (diolah)

Ket: STS= Sangat Tidak Setuju, TS=Tidak Setuju, R=Ragu-ragu, S=Setuju, SS=Sangat Setuju

Distribusi Jawaban Responden pada Variabel Sanksi Hukum

\begin{tabular}{|c|c|c|c|c|c|c|c|c|c|}
\hline \multirow[b]{2}{*}{ No } & \multirow[b]{2}{*}{ Indikator } & \multicolumn{5}{|c|}{ Frekuensi Jawaban } & \multirow[b]{2}{*}{$\begin{array}{c}\text { Skor } \\
\text { Empirik }\end{array}$} & \multirow[b]{2}{*}{$\begin{array}{l}\text { Nilai } \\
\text { Maks }\end{array}$} & \multirow[b]{2}{*}{$\begin{array}{c}\text { Pencapaian } \\
(\%)\end{array}$} \\
\hline & & $\begin{array}{c}\text { STS } \\
(1)\end{array}$ & $\begin{array}{l}\text { TS } \\
(2)\end{array}$ & $\begin{array}{c}\mathbf{R} \\
(3)\end{array}$ & $\begin{array}{c}S \\
(4)\end{array}$ & $\begin{array}{l}\text { SS } \\
(5)\end{array}$ & & & \\
\hline 1 & SH1 & 0 & 0 & 9 & 114 & 67 & 818 & 950 & 86.11 \\
\hline 2 & SH2 & 0 & 0 & 11 & 113 & 66 & 815 & 950 & 85.79 \\
\hline 3 & SH3 & 0 & 0 & 21 & 119 & 50 & 789 & 950 & 83.05 \\
\hline 4 & SH4 & 0 & 0 & 7 & 115 & 68 & 821 & 950 & 86.42 \\
\hline 5 & SH5 & 0 & 2 & 5 & 69 & 114 & 865 & 950 & 91.05 \\
\hline 6 & SH6 & 6 & 18 & 28 & 97 & 41 & 719 & 950 & 75.68 \\
\hline 7 & SH7 & 9 & 37 & 35 & 70 & 39 & 663 & 950 & 69.79 \\
\hline 8 & SH8 & 5 & 42 & 26 & 72 & 45 & 680 & 950 & 71.58 \\
\hline & Jumlah & 20 & 99 & 142 & 769 & 490 & 6170 & 7600 & 81.18 \\
\hline
\end{tabular}

Sumber: Hasil Kuesioner Penelitian, 2015 (diolah)

Ket: STS= Sangat Tidak Setuju, TS=Tidak Setuju, R=Ragu-ragu, $S=$ =Setuju, SS=Sangat Setuju

Distribusi Jawaban Responden pada Variabel Perilaku Aparatur

\begin{tabular}{|c|c|c|c|c|c|c|c|c|c|}
\hline \multirow[b]{2}{*}{ No } & \multirow[b]{2}{*}{ Indikator } & \multicolumn{5}{|c|}{ Frekuensi Jawaban } & \multirow{2}{*}{$\begin{array}{c}\text { Skor } \\
\text { Empirik }\end{array}$} & \multirow{2}{*}{$\begin{array}{l}\text { Nilai } \\
\text { Maks }\end{array}$} & \multirow{2}{*}{$\begin{array}{c}\text { Pencapaian } \\
(\%)\end{array}$} \\
\hline & & $\begin{array}{c}\text { STS } \\
\text { (1) }\end{array}$ & $\begin{array}{l}\text { TS } \\
(2)\end{array}$ & $\begin{array}{c}\mathbf{R} \\
(3)\end{array}$ & $\begin{array}{c}S \\
(4)\end{array}$ & $\begin{array}{l}\text { SS } \\
(5)\end{array}$ & & & \\
\hline 1 & PA1 & 1 & 4 & 5 & 116 & 64 & 808 & 950 & 85.05 \\
\hline 2 & PA2 & 1 & 2 & 15 & 118 & 54 & 792 & 950 & 83.37 \\
\hline 3 & PA3 & 1 & 8 & 32 & 120 & 29 & 738 & 950 & 77.68 \\
\hline 4 & PA4 & 0 & 4 & 21 & 103 & 62 & 793 & 950 & 83.47 \\
\hline 5 & PA5 & 0 & 1 & 5 & 106 & 78 & 831 & 950 & 87.47 \\
\hline 6 & PA6 & 10 & 43 & 40 & 75 & 22 & 626 & 950 & 65.89 \\
\hline 7 & PA7 & 2 & 0 & 9 & 127 & 52 & 797 & 950 & 83.89 \\
\hline 8 & PA8 & 3 & 3 & 7 & 121 & 56 & 794 & 950 & 83.58 \\
\hline \multicolumn{2}{|c|}{ Jumlah } & 18 & 65 & 134 & 886 & 417 & 6179 & 7600 & 81.30 \\
\hline
\end{tabular}

Sumber: Hasil Kuesioner Penelitian, 2015 (diolah)

Ket: STS= Sangat Tidak Setuju, TS=Tidak Setuju, R=Ragu-ragu, S=Setuju, SS=Sangat Setuju 


\section{Regresi Linier Berganda}

Coefficients $^{\mathbf{a}}$

\begin{tabular}{|c|c|c|c|c|c|c|}
\hline \multirow{2}{*}{\multicolumn{2}{|c|}{ Model }} & \multicolumn{2}{|c|}{$\begin{array}{c}\text { Unstandardized } \\
\text { Coefficients }\end{array}$} & \multirow{2}{*}{$\begin{array}{l}\text { Standardized } \\
\text { Coefficients }\end{array}$} & \multirow[b]{2}{*}{$\mathrm{t}$} & \multirow[b]{2}{*}{ Sig. } \\
\hline & & B & Std. Error & & & \\
\hline \multirow[t]{4}{*}{1} & (Constant) & 1.448 & .365 & & 3.969 & .000 \\
\hline & Kompetensi & .335 & .084 & .276 & 4.007 & .000 \\
\hline & Kompensasi & .105 & .065 & .121 & 1.623 & .106 \\
\hline & Sanksi Hukum & .194 & .062 & .229 & 3.103 & .002 \\
\hline
\end{tabular}

Berdasarkan Tabel di atas dapat diambil kesimpulan sebagai berikut:

Nilai koefesien regresi untuk variabel Kompetensi diperoleh sebesar 0,335 dengan nilai t-hitung sebesar 4,007 dan $p$-value sebesar 0,000. Karena p-value $<5 \%$, maka $\mathrm{H}_{0}$ ditolak. Artinya dengan kepercayaan sebesar $95 \%$ dapat dinyatakan bahwa jika Kompensasi dan Sanksi Hukum dianggap tetap, maka Kompetensi berpengaruh positif dan signifikan terhadap Perilaku Aparatur.

Koefesien regresi untuk variabel Kompensasi diperoleh sebesar 0,105 dengan nilai t-hitung sebesar 1,623 dan $p$ value sebesar 0,106. Karena $p$-value $>5 \%$, maka $\mathrm{H}_{0}$ diterima. Artinya dengan kepercayaan sebesar $95 \%$ dapat dinyatakan bahwa jika Kompetensi dan Sanksi Hukum dianggap tetap, maka Kompensasi tidak berpengaruh signifikan terhadap Perilaku Aparatur.

Nilai koefesien regresi untuk variabel Sanksi Hukum diperoleh sebesar 0,194 dengan nilai t-hitung sebesar 3,103 dan $p$-value sebesar 0,002. Karena $p$-value $<5 \%$, maka $\mathrm{H}_{0}$ ditolak. Artinya dengan kepercayaan sebesar $95 \%$ dapat dinyatakan bahwa jika Kompetensi dan Kompensasi dianggap tetap, maka Sanksi Hukum berpengaruh positif dan signifikan terhadap Perilaku Aparatur.

\section{Koefisien Determinasi}

\section{Rangkuman Model Regresi Linier Berganda Model Summary ${ }^{b}$}

\begin{tabular}{|l|c|r|r|r|}
\hline Model & $\mathrm{R}$ & R Square & Adjusted R Square & Std. Error of the Estimate \\
\hline 1 & $.476^{\mathrm{a}}$ & .226 & .214 & .37140 \\
\hline
\end{tabular}

a. Predictors: (Constant), Sanksi Hukum, Kompetensi, Kompensasi

b. Dependent Variable: Perilaku Aparatur

Berdasarkan Tabel di atas, diperoleh nilai korelasi ganda sebesar 0,476. Nilai tersebut menunjukkan adanya hubungan positif yang erat antara Kompetensi, Kompensasi dan Sanksi Hukum secara bersama-sama dengan Perilaku Aparatur.
Nilai koefesien determinasi $\left(\mathrm{R}^{2}\right)$ sebesar 0,226 . Hal ini menunjukkan bahwa model tersebut dapat menjelaskan variasi data yang ada sebesar 22,6 persen. Dengan kata lain, terdapat pengaruh Kompetensi, Kompensasi dan Sanksi Hukum secara 
bersama-sama terhadap Perilaku Aparatur sebesar 22,6 persen.

Uji Simultan (F)

Analisis Varians dan Hasil Pengujiannya

ANOVA $^{\mathbf{a}}$
\begin{tabular}{|l|r|r|r|c|c|}
\hline Model & Sum of Squares & Df & Mean Square & F & Sig. \\
\hline 1 Regression & 6.182 & 2 & 3.091 & 21.419 & 1 \\
Residual & 26.985 & 187 & .144 & & \\
\multicolumn{1}{|l|}{ Total } & 33.167 & 189 & & & \\
\hline
\end{tabular}

a. Dependent Variable: Perilaku Aparatur

b. Predictors: (Constant), Kompensasi, Kompetensi

Berdasarkan Tabel diperoleh nilai Fhitung sebesar 21,419 atau nilai p-value (Sig.) sebesar 0,000, karena nilai $p$-value < $\alpha$, maka $\mathrm{H}_{0}$ ditolak. Artinya, pada taraf nyata sebesar 5\% dapat dinyatakan bahwa ada pengaruh yang positif dan signifikan antara Kompetensi dan Kompensasi secara bersama-sama terhadap Perilaku Aparatur dalam pengadaan barang/jasa di Kota Palembang.
Hasil pengujian secara simultan menunjukkan adanya pengaruh positif dan signifikan antara Kompetensi dan Kompensasi terhadap Perilaku Aparatur. Artinya semakin baik Kompetensi dan Kompensasi, maka Perilaku Aparatur dalam pengadaan barang/jasa di Kota Palembang juga akan semakin baik.

\section{Analisis Varians dan Hasil Pengujiannya}

ANOVA $^{\mathrm{a}}$

\begin{tabular}{|ll|r|r|r|c|c|}
\hline \multicolumn{1}{|l|}{ Model } & Sum of Squares & Df & Mean Square & F & Sig. \\
\hline 1 & Regression & 7.510 & 3 & 2.503 & 18.148 & $.000^{\mathrm{b}}$ \\
& Residual & 25.657 & 186 & .138 & & \\
& Total & 33.167 & 189 & & & \\
\hline
\end{tabular}

a. Dependent Variable: Perilaku Aparatur

b. Predictors: (Constant), Sanksi Hukum, Kompetensi, Kompensasi

Berdasarkan Tabel diperoleh nilai Fhitung sebesar 18,148 atau nilai $p$-value (Sig.) sebesar 0,000, karena nilai $p$-value < $\alpha$, maka $\mathrm{H}_{0}$ ditolak. Artinya, pada taraf nyata sebesar $95 \%$ dapat dinyatakan bahwa ada pengaruh yang positif dan signifikan antara Kompetensi, Kompensasi dan Sanksi Hukum secara bersama-sama terhadap Perilaku Aparatur dalam pengadaan barang/jasa di Kota Palembang.

Hasil dari analisis menunjukan bahwa koefisien regresi variable Kompetensi $(\mathrm{X} 1)=$ 0,335 Kompensasi(X2) $=0,105$ Sanksi Hukum $=0,194$ dan menghasilkan nilai konstanta 1,448 sehingga persamaan regresi linier berganda $Y=a+\beta 1 X 1+\beta 2 X 2+$ 
$\beta 3 \mathrm{X} 3+\mathrm{e}$ atau $\mathrm{Y}=1,448+0,335 \mathrm{X} 1+$ $0,105 X 2+0,194 X 3+$ e ini berarti setiap penambahan per satuan variable (X1) Kompetensi, maka variable Perilaku Aparatur akan meningkat sebesar 0,335 dan setiap penambahan per satuan variable (X2) Kompensasi, maka veriabel Perilaku Aparatur akan meningkat sebesar 0,105 dan setiap penambahan per satuan variable (X3) Sanksi Hukum, maka variable Perilaku Aparatur akan meningkat sebesar 0,194.

\section{Pengujian Hipotesis}

1. Uji Parsial(t)

Hipotesis Pertama

Ho. $\beta 1=0$ Tidak terdapat pengaruh positif dan signifikan Kompetensi terhadap Perilaku Aparatur

Ha. $\beta 1>0$ Terdapat pengaruh positif dan signifikan Kompetensi terhadap Perilaku Aparatur

Karena nilai Sig diperoleh sebesar 0,000 maka Ho ditolak

Kesimpulan : Terdapat pengaruh positif dan signifikan Kompetensi terhadap Perilaku Aparatur

\section{Hipotesis Kedua}

Ho. $\beta 2=0$ Terdapat pengaruh positif dan signifikan Kompensasi terhadap Perilaku Aparatur.

Ha. $\beta 2>0$ Tidak terdapat pengaruh positif dan signifikan Kompensasi terhadap Perilaku Aparatur

Karena nilai Sig diperoleh sebesar 0,105 maka Ho diterima

Kesimpulan : Tidak terdapat pengaruh antara Kompensasi terhadap Perilaku Aparatur

\section{Hipotesis Ketiga}

Ho. $\beta 2=0$ Tidak terdapat pengaruh positif dan signifikan Kompetensi dan Kompensasi secara bersama sama terhadap Perilaku Aparatur

Ha. $\beta 2>0$ Terdapat pengaruh positif dan signifikan Kompetensi dan Kompensasi secara bersama sama terhadap Perilaku Aparatur

Karena nilai Sig diperoleh sebesar 0,000 dan $\mathrm{F}$ hitung sebesar 21,148> F tabel maka Ho ditolak

Kesimpulan : Terdapat pengaruh positif dan signifikan Kompetensi dan Kompensasi secara bersama sama terhadap Perilaku Aparatur

\section{Hipotesis Keempat}

Ho. $\beta 1=0$ Tidak terdapat pengaruh positif dan signifikan Sanksi Hukum terhadap Perilaku Aparatur

Ha. $\beta 1>0 \quad$ Terdapat pengaruh positif dan signifikan Sanksi Hukum terhadap Perilaku Aparatur

Karena nilai Sig diperoleh sebesar 0,000 maka Ho ditolak

Kesimpulan : Terdapat pengaruh positif dan signifikan Sanksi Hukum terhadap Perilaku Aparatur

Hipotesis Kelima

Ho. $\beta 2=0$ Tidak terdapat pengaruh positif dan signifikan Kompetensi dan Kompensasi dan Sanksi Hukum secara bersama sama terhadap Perilaku Aparatur Ha. $\beta 2>0$ Terdapat pengaruh positif dan signifikan Kompetensi , Kompensasi dan Sanksi Hukum secara bersama sama terhadap Perilaku Aparatur

Karena nilai Sig diperoleh sebesar 0,000 dan F hitung sebesar 18,419> F table maka Ho ditolak 
Kesimpulan : Terdapat pengaruh positif dan signifikan Kompetensi, Kompensasi dan Sanksi Hukum secara bersama sama terhadap Perilaku Aparatur

\section{Kesimpulan dan Implikasi Manajemen}

Keseluruhan hasil analisis data penelitian disimpulkan sebagai berikut :

\section{A. Kesimpulan}

Berdasarkan hasil analisis dan pengujian secara statistik terhadap data penelitian ini Pengaruh Kompetensi dan Kompensasi Terhadap Sanksi Hukum Serta Implikasinya Perilaku Aparatur, dapat disimpulkan sebagai berikut:

Kompetensi berpengaruh positif dan siginifikan terhadap Perilaku Aparatur di Kota Palembang. Besarnya pengaruh kompetensi terhadap perilaku aparatur sebesar 0,335 artinya semakin baik kompetensi maka perilaku aparatur di Kota Palembang juga akan semakin baik, pengaruh kompetensi dimaksud didukung oleh pemahaman secara komprehensip tentang peraturan pengadaan barang/jasa mutlak harus dipahami oleh aparatur dan kelengkapan dokumen lelang merupakan hal yang penting dilakukan dukungan tersebut sebesar 0,90 pada indikator KP 01 dan KP 07 (lihat tabel ) dan hasil pengujian diperoleh nilai t-hitung sebesar 4,007 karena nilai t-hitung lebih besar dari t-tabel $(1,96)$ maka dengan kepercayaan 95\% dapat dinyatakan bahwa kompetensi berpengaruh signifikan terhadap perilaku aparatur di Kota Palembang (lihat table )

Kompensasi tidak berpengaruh terhadap perilaku aparatur di Kota Palembang. Besarnya pengaruh kompensasi terhadap perilaku aparatur sebesar 0,105. Artinya dengan penambahan kompensasi belum tentu akan mempengaruhi perilaku aparatur dalam pengadaan barang/jasa, hal tersebut didukung dengan perlindungan keamanan dari tekanan dan ancaman pihak-pihak yang tidak bertanggung jawab, dukungan tersebut sebesar 0,89 pada indikator $\mathrm{KO} 07$ (lihat table ) dan hasil pengujian diperoleh nilai t-hitung sebesar 1,623 lebih kecil dari t-tabel $(1,96)$ (lihat tabel ) maka dengan kepercayaan 95\% dapat dinyatakan bahwa kompensasi tidak berpengaruh signifikan terhadap perilaku aparatur di Kota Palembang. Hal ini berarti bahwa perubahan kompensasi tidak akan berdampak pada perilaku aparatur dalam pengelolaan pengadaan barang/jasa di Kota Palembang.

Sanksi Hukum berpengaruh terhadap perilaku aparatur, besarnya pengaruh Sanksi Hukum terhadap perilaku aparatur sebesar 0,194 artinya semakin baik sanksi hukum ditegakan, maka semakin baik pula perilaku aparatur dalam pengadaan barang/jada, pengaruh sanksi hukum dimaksud didukung dengan ketegasan aparatur dalam menyiapkan dokumen lelang, yang di isyaratkan bahwa pemalsuan dokumen lelang merupakan tindakan pidana dalam pengadaan barang/jasa dukungan tersebut sebesar 0,115 pada indikator SH 05 (lihat table ) dan hasil pengujian diperoleh nilai t-hitung sebesar 3,103 lebih besar dari t-tabel $(1,96)$ maka dengan kepercayaan 95\% dapat dinyatakan bahwa sanksi hukum berpengaruh positif dan signifikan terhadap perilaku aparatur di Kota Palembang. Hal ini berarti bahwa perubahan penegakan hukum akan berdampak pada perilaku aparatur dalam pengelolaan pengadaan barang/jasa di Kota Palembang

Kompetensi dan Kompensasi secara bersama-sama berpengaruh positif dan signifikan terhadap perilaku aparatur dan 
hasil pengujian diperoleh F-hitung sebesar 21,419 lebih besar dari F-tabel $(3,683)$ atau nilai $\mathrm{P}$-value sebesar $0,000<\alpha$ maka dengan kepercayaan $95 \%$ dapat dinyatakan bahwa kompetensi dan kompensasi secara bersama-sama berpengaruh positif dan signifikan terhadap perilaku aparatur di Kota Palembang. Hal ini berarti bahwa perubahan kompetensi dan kompensasi akan berdampak pada perilaku aparatur dalam pengelolaan pengadaan barang/jasa di Kota Palembang.

Kompetensi, Kompensasi dan sanksi hukum secara bersama-sama berpengaruh terhadap perilaku aparatur di Kota Palembang dan hasil pengujian diperoleh F-hitung sebesar 18,148 lebih besar dari Ftabel $(3,683)$ atau nilai p-value sebesar $0,000<\alpha$ pengaruh dimaksud di dukung bahwa setiap tindakan aparatur dalam mengambil keputusan harus berdasarkan aturan dan logika dalam pengadaan barang/jasa, dukungan tersebut sebesar 0,78 pada indicator PA 05 maka dengan kepercayaan $95 \%$ dapat dinyatakan bahwa kompetensi, kompensasi dan sanksi hukum secara bersama-sama berpengaruh positif dan signifikan terhadap perilaku aparatur di Kota Palembang. Hal ini berarti bahwa perubahan kompetensi, kompensasi dan sanksi hukum akan berdampak pada perilaku aparatur dalam pengelolaan pengadaan barang/jasa di Kota Palembang.

\section{B. Implikasi Manajerial}

Berdasarkan hasil analisis dan kesimpulan pada bagian sebelumnya, penelitian ini memperoleh beberapa bukti empiris yang dapat dijadikan masukan bagi Pemerintah Kota palembang, dalam rangka menerapkan implementasi strategi bagi aparatur dalam pengelolaan barang/jasa.
Secara simultan Perilaku aparatur dipengaruhi oleh Kompensasi dan Kompetensi, namun secara parsial hanya Kompetensi yang berpengaruh positif dan siginifikan terhadap perilaku aparatur di Kota Palembang, maka implikasinya adalah, bahwa pemberian kompensasi bagi pengelola pengadaan barang/jasa bukanlah tujuan utama aparatur untuk dapat memeberikan motivasi kerjanya melainkan faktor, adanya jaminan perlindungan keamanan bagi panitia lelang terhadap tekanan dan ancaman dari pihak-pihak yang tidak bertanggung jawab.

Secara simultan, Perilaku aparatur dipengaruhi secara positif dan signifikan oleh Kompetensi, Kompensasi dan Sanksi Hukum, artinya bahwa jika ingin meningkatkan kinerja aparatur, maka ketiga variabel tersebut, perlu ditingkatkan secara simultan. Namun secara parsial menunjukkan bahwa variable sanksi hukum mempunyai pengaruh paling dominan dibandingkan dengan variable Kompetensi dan variable Kompensasi yaitu pada indikator pemalsuan dokumen lelang merupakan suatu tindakan pidana untuk itu perlu peningkatan Kompetensi aparatur sebagai dasar dalam pelaksanaan pengelolaan pengadaan barang/jasa.

\section{Refferency :}

Agung. (2008). Dasar-dasar Perilaku Individu [online].Tersedia: http://agungpia.multiply.com /journal/item/23.html (diakses tanggal 28 September 2010).

Agbo, F.U. 2000, Increasing the output of caorava through women cooperatives Nigerian Journal of cooperative studi 2(1).PP.24-38

Aubrey, Daniels C. 2000, Maximum Performance: Sistem Motivasi 
terbaik Bagi Kinerja Karyawan, Jaqkarta, PT.Buana Ilmu Popiler Arep, Ishak dan Tanjung, Hendri (2003) Manajemen Motivasi, Jakarta, PT.Gramedia Widiasarana Indonesia.

Alex, S. Nitisemito, 2000. Manajemen Personalia, Manajemen Sumber Daya Manusia, Jakarta, Gholia Indonesia.

Anto Dajan, 2000. Pengantar Metode Statistik Jilid 2, Jakarta Penerbit LP3ES.

Achmad S, Ruky, 2001, Sistem Manajemen Kinerja, Jakarta : PT, Gramedia Pustaka utama.

Anoraga, (2009) Sistem kompensasi, Jakarta. penerbit Rineka cipta

Andhika Putra Kresnandito, 2012 Pengaruh Persepsi Kepemimpinan Transformasional terhadap perilaku inovatif karyawan, Jurnal Fak. Psikologi Universitas Airlangga, Vol 1 Nomor 2.

Ambruster, P. 2001. Cooperative Banks in Europe Value and Practices to Produc development IRU Courier (3) PP. 10-13

A.Soegihartono, 2012. Pengaruh Kepemimpinan dan Kepuasan kerja terhadap kinerja dengan mediasi komitmen, Jurnal Fak, Ekonomi Univ, Dian Nuswantoro Semarang, Vol 3 Nomor 1. 2003, SDM Berkualitas Mengubah Visi menjadi Realitas, Pendekatan Mikro Praktis Untuk Memperoleh dan Mengembangkan Sumber Daya Manusia Berkualitas dalam Organisasi, Jakarta : PT, Gramedia Pustaka Utama.
Arikunto, Suharmini ,2005, Manajemen Penelitia,Edisi Revisi, Jakarta Rineka Cipta. 2006, Prosedur Penelitian Suatu Pendekatan Praktek, Edisi Revisi Jakarta Rineka Cipta.

As'ad, Moh, 2000, Psikologi Industri, Yogyakarta Liberty.

Azmi, Ghani, 2010 Competency Based Human Resource Practices in Malaysian Public Sector Organization, African Journal of Business Management Vol 4(2),PP.235-241.

Bass, B.M. \&R.E. Ringgo 2006. Tranformational leadership, New York, Lawrence Erbaum Associates Publisher.

Bangun Wilson, 2012. Manajemen Sumber Daya Manusia, Bandung. Erlangga.

Boland, L.A, 2005. Critical Economic Method. London George Allen and Unwin.

Boland, L.A. 2000. The Methodology of Economic Model Building: Methodology after samuelson. New York. Routiedge.

Budiyuwono, Nugroho, 2003. Pengantar Statistik Ekonomi dan Perusahaan, Yogyakarta. AMP YKPN.

Birdir, Edwin, 2000, Human Resources Planning, New York McGrawHill Book Company.

Byrne, B.M, 2001, Structural Equation Modeling With Amos Basic Concep-t, Aplication Programming. Lawrence Erlbaum Associates.

Casio, F.C.2003. Managing Human Resources Prodauctivity, Quality of Work Life, Proffitss, Six Edition. Bosto McGraw-Hill. 
Chaney, C.2006. TheLeader's Tool Kit Hundreads of Tips and Techniques for Developing he Skill you Need, New York, Amacom.

Cooper, D.R. and P.S. Schindler. 2003. Busines Research Methods, Singapore, McGraw-Hill International.

Collins,J, 2006, Good to Great, New York, Summit.

Cortina, J.M, 2002. Testing Interacting Effects in LISREL, Examinationand Illustration of Available Procedures, Organization Research Method

Darlius, 2009, Disertasi Pengaruh Kepemimpinan dan kompetensi, terhadap Motivasi Implikasinya pada Kinerja Karyawan, Jakarta. Universitas Persada Indonesia. YAI.

Delahaye,B. 2011, Development Managing Learning Knowledge Capital Human Resoucess, Third Edition, Pahlan, VIC, Australia, Tidle university Press.

Dressler, G, 2003. Human Resourcess Management, Nineth Edition, New Jersey, Upper Seddler River, Prentice Hall.

Davis Keith, New Strom, Jhon W, 2002, Perilaku Dalam Organisasi, Jilid I, Alih Bahasa Agus Darma Jakarta Erlangga.

Dessler Gary, 2002, Human Resource Management, Sage Publication. Eighth Edition, New Jersey By Prentice Hall, Inc, Upper Saddle River.

Diamantopaulus, A. Dan Siguaw,J.A, 2000. Introducing LISREL. A guide for the Uniate. London,Sage.
Ernes J, Mc Cormick, Fitgerald E, 2001, "People and Organizational Culture: A Profile Comparison Approach to Assessing PersonOrganization Fit", Academy of Management Journal, April 2001, pp, 487-513.

Erlbaum, L. 2003. Transformational leadership, Industrial, Military, and Education Impact England Bernand M.Bass,NSCL.

Gallos, Joan, 2008, Business Leadership, New Jersey John Willey \& Son

Ghozali, Imam, 2006, Analisis Multivariate Lanjutan, Semarang, Penerbit UNDIP.

Gibson, James, L; John, M, Ivancevich dan J,H, Donelly, 2004, Organisasi dan Manajemen, Perilaku, Struktur, Proses, Terj, Djoerban Wahid, Jakarta : Erlangga,

Gibson, J.L.J.M. Invencenth, et.all. 2009 Organization

Bahavior, Structure, Process, Thirteenth Edition, New York Mcgraw Hill

Gill, R. 2009. Theory and Practice of Leadership, New York, A. Sage Publication Company. 